\title{
Field Evaluation of Tomato Cultivars for Tolerance to Tomato Chlorotic Spot Tospovirus
}

\author{
Shouan Zhang, ${ }^{1,+}$ Xiaohui Fan, ${ }^{1}$ Yuqing Fu, ${ }^{1}$ Qingren Wang, ${ }^{2}$ Eugene McAvoy, ${ }^{3}$ and Dakshina R. Seal ${ }^{1}$ \\ ${ }^{1}$ University of Florida, Tropical Research and Education Center, Homestead, FL 33031 \\ ${ }^{2}$ UF/IFAS Miami-Dade County Extension, Homestead, FL 33030 \\ ${ }^{3}$ UF/IFAS Hendry County Extension, LaBelle, FL 33935
}

Accepted for publication 20 March 2019.

\section{Abstract}

Fourteen tomato cultivars resistant to tomato spotted wilt tospovirus (TSWV) were evaluated for their tolerance against tomato chlorotic spot tospovirus (TCSV) under field conditions during the 2014-2015 and 2015-2016 growing seasons in Homestead, FL. All TSWV-resistant tomato cultivars had significantly $(P<0.05)$ lower disease incidence of TCSV, compared with the commercial standard cultivars 'FL 47' or 'Sanibel', exhibiting intermediate to high levels of tolerance to TCSV. There was no significant effect of tomato genotype on the thrips vectors, western flower thrips (Frankliniella occidentalis) and common blossom thrips ( $F$. schultzei). All tested tomato cultivars had equivalent or greater yields of total marketable fruit compared with the standard cultivar Sanibel. Particularly, in the third trial with disease incidence of $25 \%$ on Sanibel, 'BHN 1064 ' had significantly greater total yield and yields of extra-large and large fruit compared with Sanibel. 'SV 7631TD' and 'Brickyard' had significantly greater extra-large fruit yield and medium fruit yield, respectively, compared with Sanibel. Results from this study show that TSWV-resistant tomato cultivars were tolerant to TCSV under field conditions of south Florida, indicating that the use of genetic resistance in commercial tomato cultivars is an effective strategy to manage TCSV.

Keywords: tomato chlorotic spot tospovirus, integrated pest management, host resistance, tomato, thrips, yield
In the United States, tomato chlorotic spot tospovirus (TCSV) (family Bunyaviridae, genus Tospovirus) was first reported in tomato (Lycopersicon esculentum) and bell pepper (Capsicum annuum) from south Florida in 2012 (Londoño et al. 2012). Outbreaks of the disease caused by TCSV have occurred since 2014, causing significant losses to tomato growers in south Florida, particularly in Homestead, Miami-Dade County (Zhang et al. 2015b, 2016). In the fall of 2014, 20 to $40 \%$ of tomato plants were infected with TCSV in commercial tomato fields of Homestead. Growers rogued infected plants from the fields in the hopes of reducing the spread of the disease. In November 2014, initial symptoms of the disease including necrotic lesions and chlorotic spots were observed on top leaves of plants in tomato fields at 3 weeks after transplanting (WAT). Within 1 week following the initial symptoms, the disease progressed rapidly to cause terminal stem and leaf death, wilting, bronzing, necrosis, and deformation of leaves. Infection of TCSV in tomato plants prior to flowering resulted in severe stunting of plant growth with few or no flowers and in eventual death of the entire

Corresponding author: S. Zhang; E-mail: szhang0007@ufl.edu

Funding: This work was supported by the USDA National Institute of Food and Agriculture Crop Protection and Pest Management (CPPM) Applied Research and Development Program (ARDP) project (2015-70006-24165), Florida Department of Agriculture and Consumer Services (FDACS) Specialty Crop Block Grant (award no. USDA-AMS-SCBGP-2015), and Florida Tomato Committee (2014-2015).

The author(s) declare no conflict of interest.

*The e-Xtra logo stands for "electronic extra" and indicates that one supplementary figure is published online.

(C) 2019 The American Phytopathological Society plants. More severe stunting of plant growth occurred if the plants were infected earlier with TCSV. Fruit from infected plants, if any, showed necrotic rings, often rendering them unmarketable.

TCSV is analogous to TSWV, groundnut ringspot tospovirus (GRSV), and other known tospoviruses (Whitfield et al. 2005). Similar to other tospoviruses, TCSV is known to be exclusively transmitted by thrips. To date, two species of flower thrips, western flower thrips (Frankliniella occidentalis) and common blossom thrips ( $F$. schultzei), are confirmed to be the main vectors of TCSV in south Florida (Webster et al. 2015). F. occidentalis is a major vector of many tospoviruses including TCSV and TSWV and is commonly present in the United States and worldwide (Riley et al. 2011; Wijkamp et al. 1995). F. schultzei is not widespread in Florida and the United States; however, it has been reported recently in vegetable production areas of south Florida and Puerto Rico where TCSV was detected (Estévez de Jensen and Adkins 2014; Kakkar et al. 2012a, b; Webster et al. 2013). The potential of other thrips species to transmit TCSV in Florida and other states of the United States has not been determined.

TCSV was also reported from annual vinca (Catharanthus roseus) in south Florida (Warfield et al. 2015), ornamental crops (Hoya wayetii, Schlumbergera truncata) in central Florida (Baker and Adkins 2015), and Madagascar jasmine (Marsdenia floribunda) in Florida (Dey et al. 2017). TCSV was also reported to infect an herbal crop sweet basil (Ocimum basilicum), a weed purslane (Portulaca oleracea) (Raid et al. 2017), and jimsonweed (Datura stramonium) (Webster et al. 2013). In 2017, we first detected TCSV in snap bean (Phaseolus vulgaris) in Homestead, FL (Poudel et al. 2018). Other experimental hosts of TCSV in the United States include tomatillo (Physalis philadelphica), tobacco 
(Nicotiana benthamiana), petunia (Petunia $\times$ hybrid), and impatiens (Impatiens walleriana) (Webster et al. 2015). The recent identification of several plant species as the natural hosts of TCSV in south and central Florida has implications for epidemiology and management of TCSV in ornamental as well as vegetable crops, because they often share production space in Florida. TCSV infection of vegetable and ornamental crops will also likely lead to further geographic spread of this emerging virus. Considering the widespread distribution of TCSV in south Florida, where vegetable fields, ornamental nurseries, tropical and subtropical fruit groves, and transplant producers are in close proximity, many other crops and weed species may be potential reservoirs or hosts of TCSV.

There has been a great concern that TCSV may spread beyond south or central Florida to other areas owing to the widespread presence of thrips vectors and transplant producers in this area. In addition to the reports of TCSV in Florida, TCSV was also reported in tomato in Ohio during the summer of 2013 (Baysal-Gurel et al. 2015) and in New York in 2017 (Sui et al. 2018). These are the reports of TCSV outside of Florida infecting tomatoes in the United States, highlighting the great potential of TCSV spreading to other U.S. states. Therefore, in Florida, appropriate management strategies must be taken into consideration in vegetable fields and ornamental nurseries not only to reduce losses to those crops but also to restrict the movement of TCSV out to other U.S. states.

Because TCSV is an emerging tospovirus in the United States, no effective management practices for TCSV are available. Insecticides such as cyantraniliprole and spinetoram significantly suppressed flower thrips populations in south Florida; however, the control levels of TCSV disease were not satisfactory (Zhang et al. 2015a). Considering the high similarity between TCSV and TSWV, selection of TSWV-resistant tomato cultivars could hold promise to reduce yield losses owing to infection with TCSV (Polston et al. 2013). Previous studies showed that tomato lines carrying the $S w-5$ gene, which confers resistance to TSWV, also provided resistance to TCSV in studies conducted in other countries (Kang et al. 2005; Soler et al. 2003). However, the host genetic background can affect the performance of resistance genes. There have been no reports yet of host resistance in tomato to TCSV under the commercial production conditions in the United States. In the 2014-2015 and 2015-2016 vegetable growing seasons, we conducted three field trials in Homestead, FL, under commercial production conditions to evaluate tomato cultivars for their resistance to TCSV. Tomato fruit were harvested and graded, and marketable yields were determined in two of the three trials. In addition, the density of two thrips vectors, western flower thrips and common blossom thrips, was monitored and assessed.

\section{Plant Materials, Field Design, and Maintenance}

A total of 14 tomato cultivars (13 round type and one Roma type) provided by collaborative seed companies were evaluated in three field trials, along with cultivar 'FL 47' or 'Sanibel' as a commercial standard check known to be susceptible to TCSV (Table 1). All field trials were conducted in Homestead, FL, during the 2014-2015 and 2015-2016 tomato growing seasons. The first trial (trial 1) was conducted in the spring of 2015 during the 2014-2015 season, and the other two trials (trials 2 and 3) were carried out in the fall of 2015 during the 2015-2016 season. Tomato plants were grown in raised beds covered with plastic mulch that were prepared for vegetable cultivation in south Florida. White plastic mulch was used in trial 1 during the 2014-2015 season, and black plastic mulch was laid out for trials 2 and 3 in the 2015-2016 season. The beds that were $0.76 \mathrm{~m}$ wide and centered $1.83 \mathrm{~m}$ apart with plants staked and tied at $0.61-\mathrm{m}$ spacing in a single 8.2- to 8.5 -m length row per plot. Irrigation and fertilization were applied through two drip irrigation tapes passing by both sides of the plants on each bed to ensure optimal requirements for tomato production. A minimum of $560 \mathrm{~kg} / \mathrm{ha}$ of a granular fertilizer 10-4.4-8.3 (N-P-K) (Helena Chemical Co., Homestead, FL) was applied to the soil of the beds before the beds were made, and following applications of a liquid fertilizer 7-0-5.8 (N-P-K) (Helena Chemical Co.) were applied at $8 \mathrm{~kg} / \mathrm{ha}$ each week through drip injection. In each trial, tomato plants were treated weekly with registered fungicides and insecticides that are ineffective for control of thrips to prevent the damages caused by diseases and other insect pests. All tomato cultivars in each trial were arranged in a randomized complete block design with four replications (plots) for each cultivar.

\section{Field Trials for Evaluation of Tomato Cultivars for Control of TCSV}

Trial 1. Seedlings of the 14 test tomato cultivars were transplanted into the beds covered white plastic mulch on February 3, 2015. FL 47, one of most commonly cultivated tomato cultivars in south Florida and known to be susceptible to TCSV, was included as a commercial standard check. Prior to transplanting, five to 10 plants of each cultivar were randomly selected and subject to a test against TSWV using an ImmunoStrip (TSWV; Agdia, Elkhart, IN) to ensure that the tomato seedlings used were tospovirus-free. Plots consisted of a single bed of $8.5-\mathrm{m}$ section with a $1.2-\mathrm{m}$ buffer zone between adjacent plots. Fourteen plants were transplanted in each plot, and a total of 56 seedlings were planted for each tomato cultivar. After initial symptoms appeared, the plants were examined for the disease in each plot twice a week at 3- to 4-day intervals

\begin{tabular}{|c|c|c|c|c|}
\hline \multicolumn{5}{|c|}{$\begin{array}{l}\text { TABLE } 1 \\
\text { Tomato cultivars, source, resistance designation, and } \\
\text { tolerance to tomato chlorotic spot tospovirus (TCSV) disease } \\
\text { in field trials conducted in Homestead, FL, during the } \\
2014-2015 \text { and } 2015-2016 \text { seasons }^{x}\end{array}$} \\
\hline \multirow[b]{2}{*}{ Cultivar } & \multirow[b]{2}{*}{ Source } & \multicolumn{2}{|c|}{ Resistance to TSWV } & \multirow[b]{2}{*}{$\begin{array}{c}\text { TCSV } \\
\text { tolerance }\end{array}$} \\
\hline & & $\begin{array}{l}\text { Resistance } \\
\text { gene }\end{array}$ & $\begin{array}{l}\text { Response } \\
\text { to TSWVy }\end{array}$ & \\
\hline Skyway & Enza Zaden & $S w-5$ & IR & $+++(3)$ \\
\hline BHN 602 & $\mathrm{BHN}$ & $S w-5$ & $\mathrm{R}$ & $+++(3)$ \\
\hline BHN 640 & $\mathrm{BHN}$ & $S w-5$ & $\mathrm{R}$ & $+++(3)$ \\
\hline BHN 1064 & BHN & $S w-5$ & $\mathrm{R}$ & $+++(3)$ \\
\hline Volante & Sakata & $S w-5$ & IR & $+++(3)$ \\
\hline XTM 8135 & Sakata & $S w-5$ & IR & $+++(3)$ \\
\hline Dixie Red & Seminis & $S w-5$ & HR & $+++(3)$ \\
\hline SV 7631TD & Seminis & $S w-5$ & HR & $+++(3)$ \\
\hline SV 7101TD & Seminis & $S w-5$ & HR & $+++(3)$ \\
\hline Quincy & Seminis & $S w-5$ & $\mathrm{R}$ & $+++(3)$ \\
\hline Brickyard & Syngenta & $S w-5$ & IR & $+++(3)$ \\
\hline $\begin{array}{l}\text { Monticello } \\
\text { (Roma) }\end{array}$ & Syngenta & $S w-5$ & IR & $+++(3)$ \\
\hline Richmond & Syngenta & $S w-5$ & IR & $+++(3)$ \\
\hline Summerpick & Syngenta & $S w-5$ & IR & $+++(3)$ \\
\hline FL 47 & Seminis & $\ldots$ & $\mathrm{S}$ & (1) \\
\hline Sanibel & Seminis & $\ldots$ & $\mathrm{S}$ & (2) \\
\hline
\end{tabular}

$\mathrm{x}$ Three field trials conducted in Homestead during the 2014-2015 and 2015-2016 seasons with more than $25 \%$ of tomato plants infected on the commercial tomato standard FL 47 or Sanibel.

${ }^{\mathrm{y}}$ This information is from the collaborative companies listed. $\mathrm{HR}=$ high resistance; $\mathrm{IR}=$ intermediate resistance; $\mathrm{R}=$ resistance; and $\mathrm{S}=$ susceptible.

${ }^{\mathrm{z}}$ Number of trials when significant TCSV tolerance (+) was detected on a specific tomato cultivar compared with the susceptible cultivars per total trials (in parentheses). 
(Monday and Friday each week) until all plants of FL 47 showed symptoms of the disease. On March 20, 2015, five samples of infected leaves showing typical symptoms from each cultivar were collected, and the presence of TCSV was confirmed by reverse transcription polymerase chain reaction (RT-PCR) (Londoño et al. 2012) using the following specific primers: TCSV-F, 5'-AGTATT ATGCATCTATAGATTAGCACA-3'; and TCSV-R, 5'-ACAA ATCATCACATTGCCAGGA-3'. The number of tomato plants with typical symptoms per plot was counted throughout the season, and percent disease incidence was calculated based on a total of 14 plants in each plot. Because of early infection of the plants with TCSV, nearly no fruit was produced on FL 47 plants. Within 10 to 11 WAT, most fruit on plants of the 14 test cultivars showed symptoms of infection with other viruses including tomato yellow leaf curl virus. Therefore, no fruit was harvested for this trial.

Trial 2. Tomato seedlings were transplanted into the beds covered with black plastic mulch on October 22, 2015. Sanibel, another susceptible tomato cultivar most commonly cultivated in south Florida, was included as a commercial standard check in this trial. Plots consisted of a single bed of 8.2-m section with a $0.91-\mathrm{m}$ buffer zone between adjacent plots. Fourteen plants were planted in each plot, and a total of 56 plants were transplanted for each tomato cultivar. When initial symptoms of the disease appeared, the plants were examined for the symptoms twice a week at 3- to 4-day intervals until January 29, 2016, when no additional plants were observed with the symptoms. On December 2, 2015, five to eight samples of infected leaves from each cultivar showing typical symptoms of TCSV were collected, and the presence of TCSV was confirmed in all samples by RT-PCR using the specific primers described previously. The number of plants with typical symptoms per plot was counted throughout the season, and percent disease incidence was calculated in each plot. Marketable fruit were harvested on January 8, January 26, and February 17, 2016, from the center five plants in each plot and graded according to the USDA standards for fresh market tomato (Sargent and Moretti 2004). Yields of extra-large, large, and medium fruits and total marketable fruit yield of each plot were separately determined.

Trial 3. This was a repeat of trial 2 and was conducted in another field in Homestead, FL, during the 2015-2016 season. This trial was similar to trial 2 in terms of experimental design, field plot layout, transplanting, and plant maintenance, except for the following: tomato seedlings were transplanted on October 23, 2015; the tomato plants were examined and recorded for typical symptoms of TCSV until January 23, 2016, when no additional plants were observed with the symptoms; and tomato fruit were harvested on January 13, February 11, and February 25, 2016.

\section{Thrips Sampling and Counting}

The number of adults of western flower thrips and common blossom thrips was determined using blossom samples. Blossom samples were collected on March 31, 2015, in trial 1 and December 1, 2015 , in trial 2 with the following procedure. Ten blossom samples (one blossom per plant) were randomly collected perform each plot and placed in a vial with $70 \%$ ethanol. Adult thrips from the samples were washed off into the ethanol solutions by shaking, and their species was identified using identification keys (Oetting et al. 1993; Stannard 1968) under $70 \times$ to $140 \times$ magnification under a SZH10 Olympus stereomicroscope (Olympus America, Lake Success, NY).

\section{Data Analysis}

Statistical analyses were performed to determine whether the independent variables such as disease incidence, marketable fruit yield, or thrips count had any interactions between tomato cultivar and growing season. Both yield and disease incidence data were analyzed by PROC GLM using the SAS statistical software version 9.4 (SAS Institute, Cary, NC) to test for cultivar-by-season interactions. Based on significance of cultivar-by-season interactions for yield and disease, analysis of variance was conducted by season (trial) using PROC GLM. Means of disease incidence, marketable yield, and thrips count per plot were separated by least significant difference tests at $P=0.05$.

\section{Disease Incidence, Marketable Yield, and Thrips Vector Monitoring on Tomato Cultivars}

Trial 1. Initial symptoms of the disease were observed on a susceptible plant of FL 47 on February 27, 2015, 24 days after transplanting. Disease incidence was then rated on February 27, March 2, 5, 9, 13, 16, 20, 23, 27, and 30, and April 3, 2015, when $100 \%$ plants of cultivar FL 47 showed typical symptoms (Supplementary Fig. S1). Presence of TCSV was confirmed in all collected samples by RT-PCR. Tomato cultivars tested in this trial showed varied levels of tolerance to TCSV (Table 2). High tolerance of the disease was found in the cultivars 'Dixie Red', 'SV

\section{TABLE 2}

Disease incidence of tomato chlorotic spot tospovirus (TCSV) and density of thrips vectors on tomato plants of tested cultivars during the 2014-2015 season (trial 1)w

\begin{tabular}{lccc} 
& & \multicolumn{2}{c}{ Thrips density } \\
\cline { 3 - 4 } Cultivar & $\begin{array}{c}\text { Disease } \\
\text { incidence (\%) }\end{array}$ & $\begin{array}{c}\text { Western flower } \\
\text { thrips }\end{array}$ & $\begin{array}{c}\text { Common } \\
\text { blossom thrips }\end{array}$ \\
\hline Skyway & $41.1 \mathrm{~b}^{\mathrm{z}}$ & 3.5 & 1.2 \\
BHN 602 & $30.4 \mathrm{~b}-\mathrm{d}$ & 0.8 & 3.2 \\
BHN 640 & $37.5 \mathrm{~b}$ & 6.3 & 1.7 \\
BHN 1064 & $35.7 \mathrm{~b}$ & 6.2 & 3.6 \\
Volante & $39.3 \mathrm{bc}$ & 4.9 & 2.5 \\
XTM8135 & $42.9 \mathrm{~b}$ & 5.8 & 2.1 \\
Dixie Red & $10.7 \mathrm{~d}$ & 5.1 & 4.7 \\
SV 7631TD & $16.1 \mathrm{~d}$ & 8.2 & 2.8 \\
SV 7101TD & $10.7 \mathrm{~d}$ & 2.6 & 5.5 \\
Quincy & $33.9 \mathrm{bc}$ & 4.8 & 3.4 \\
Brickyard & $39.3 \mathrm{bc}$ & 8.7 & 0.6 \\
Monticello & $35.7 \mathrm{bc}$ & 3.8 & 2.7 \\
$\quad$ (Roma) & & & \\
Richmond & $33.9 \mathrm{bc}$ & 0.9 & 2.5 \\
Summerpick & $30.4 \mathrm{bc}$ & 7.3 & 3.7 \\
FL 47 & $100.0 \mathrm{a}$ & 8.5 & 2.3 \\
\hline
\end{tabular}

${ }^{\mathrm{w}}$ The field trial was set up in the field on February 2, 2015. Fruit yield was not measured owing to heavy infection with other viruses including tomato yellow leaf curl virus.

${ }^{\mathrm{x}}$ Disease incidence was calculated based on number of tomato plants in each plot showing typical symptoms of TCSV in the total number of plants for a given cultivar. Ratings of TCSV disease were initiated when initial symptoms were observed on plants of susceptible FL 47 and continued on a 3- to 4-day interval until all plants of susceptible FL 47 showed symptoms.

${ }^{\mathrm{y}}$ The number of western flower thrips (Frankliniella occidentalis) and common blossom thrips (F. schultzei) adults was determined using blossom samples, in which 10 blossoms were randomly collected per plot, one blossom per plant, on March 31, 2015. No significances $(P=$ 0.05 ) in thrips density were detected among all tomato cultivars.

${ }^{\mathrm{z}}$ Means followed by the same letters within a column are not significantly different at $P=0.05$. 
7631TD', and 'SV 7101TD'. At the last disease incidence assessment on April 3, 2015, two months after transplanting, disease incidence on these three cultivars was $10.7,16.1$, and $10.7 \%$, respectively; 11 other cultivars exhibited intermediate tolerance to TCSV with 30 to $42 \%$ of plants infected, whereas $100 \%$ of the FL 47 plants displayed typical symptoms of TCSV. On the FL 47 plants, most newly developed symptoms occurred during the fifth to sixth WAT, and $100 \%$ of the plants had symptoms during the seventh WAT (Fig. 1). On other tested cultivars, new symptoms were still observed during the ninth WAT; most new symptoms were observed during the sixth to eighth WAT. The number of western flower thrips adults ranged from 2.6 to 8.7 , and that of common blossom thrips adults ranged from 1.2 to 5.5 per 10 flowers collected from the plants of tomato cultivars (Table 2). No significant differences were detected in adult numbers among the tomato cultivars.

Trial 2. Symptoms of TCSV infection were first observed on a susceptible plant of Sanibel on November 13, 2015, 22 days after transplanting. Disease incidence was rated on November 13, 20, 23 , and 27, December 3, 5, 7, 11, 14, 18, 21, 25, and 28, 2015, and January 1, 4, 15, 23, and 29, 2016, when $51.8 \%$ of Sanibel plants showed typical symptoms of TCSV and no additional plants were observed with newly developed symptoms. The presence of TCSV in all leaf samples collected with typical symptoms was confirmed by RT-PCR. The 14 tomato cultivars tested in this trial had low disease incidence (Table 3), and no symptoms were observed on the plants of 'XTM8135', Dixie Red, SV 7631TD, and SV 7101TD. The other 10 tomato cultivars showed high tolerance to TCSV with 1.7 to $7.1 \%$ of plants infected, whereas $51.8 \%$ of the Sanibel plants displayed TCSV symptoms. On the plants of cultivar Sanibel, most new symptoms of TCSV infection occurred during the fifth to 10th WAT (Fig. 2). On the 14 cultivars tested, most new symptoms were observed during the sixth to 10th WAT. The density of western flower thrips adults was from 2.1 to 6.3 , and that of common blossom thrips adults ranged from 0.8 to 4.8 per 10 flowers collected from plants of tomato cultivars (Table 3 ) with no significant

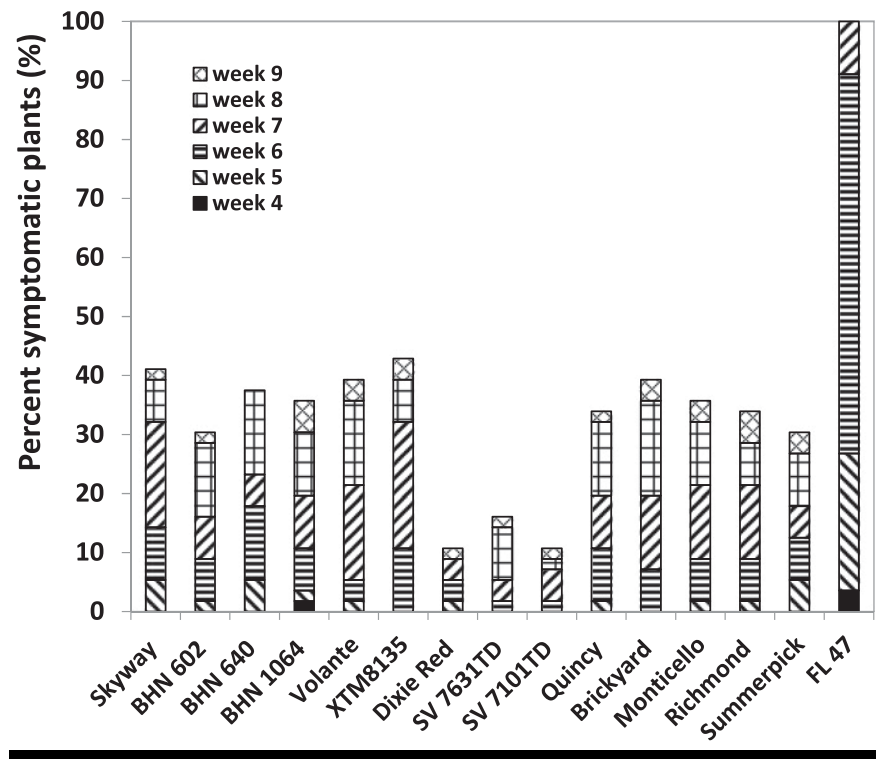

\section{FIGURE 1}

Percent of tomato chlorotic spot tospovirus infection developed weekly on tomato leaves in a field trial (trial 1) conducted during the 2014-2015 season. A commonly cultivated cultivar, FL 47 , was included as a commercial standard check. differences detected in adult numbers among the tomato cultivars. Although marketable yields of the 14 test tomato cultivars were not significantly different from that of Sanibel (Table 3), 'Volante', 'Monticello', 'Skyway', 'BHN 1064', and SV 7631TD had numerically greater yield than Sanibel. BHN 1064 was the only tomato cultivar that had significantly greater large fruit yield compared with Sanibel (data not shown).

In both trials 1 and 2, only adults of two thrips species-western flower thrips and common blossom thrips, which were known to transmit TCSV (Webster et al. 2015) —were monitored by sampling the blooms from the plants of all tomato cultivars tested in this study. No correlation between disease incidence and thrips density in the tomato field was detected (Tables 2 and 3). This is in agreement with Riley et al. (2011), who reported no detectable resistance to thrips vectors observed in the tomato TSWV-resistant lines tested under field conditions. It is not clear about the mechanisms of the genetic resistance/tolerance in these lines to TSWV or TCSV. More research is needed to investigate the mechanisms underlying the resistance or tolerance. In addition, it is likely that other species of thrips may serve as vectors of TCSV;

\section{TABLE 3}

Disease incidence of tomato chlorotic spot tospovirus (TCSV), fruit yield, and thrips density on tomato plants of tested cultivars during the 2015-2016 season (trial 2)v

\begin{tabular}{lcccc} 
& & & \multicolumn{2}{c}{ Thrips density } \\
\cline { 4 - 5 } Cultivar & $\begin{array}{c}\text { Disease } \\
\text { incidence } \\
\text { (\%) }\end{array}$ & $\begin{array}{c}\text { Total yieldx } \\
\text { (kg/plot) }\end{array}$ & $\begin{array}{c}\text { Western } \\
\text { flower } \\
\text { thrips }\end{array}$ & $\begin{array}{c}\text { Common } \\
\text { blossom } \\
\text { thrips }\end{array}$ \\
Skyway & $1.8 \mathrm{~b}^{\mathbf{z}}$ & $96.5 \mathrm{a}$ & 2.9 & 0.4 \\
BHN 602 & $3.6 \mathrm{~b}$ & $80.0 \mathrm{ab}$ & 1.5 & 1.1 \\
BHN 640 & $1.8 \mathrm{~b}$ & $85.5 \mathrm{ab}$ & 2.1 & 2.0 \\
BHN 1064 & $1.8 \mathrm{~b}$ & $96.5 \mathrm{a}$ & 2.9 & 1.3 \\
Volante & $7.1 \mathrm{~b}$ & $101.0 \mathrm{a}$ & 2.4 & 4.8 \\
XTM8135 & $0.0 \mathrm{~b}$ & $78.0 \mathrm{ab}$ & 6.1 & 2.0 \\
Dixie Red & $0.0 \mathrm{~b}$ & $76.3 \mathrm{ab}$ & 0.8 & 0.8 \\
SV 7631TD & $0.0 \mathrm{~b}$ & $97.5 \mathrm{a}$ & 4.3 & 2.5 \\
SV 7101TD & $0.0 \mathrm{~b}$ & $85.5 \mathrm{ab}$ & 5.1 & 1.8 \\
Quincy & $1.8 \mathrm{~b}$ & $82.3 \mathrm{ab}$ & 6.3 & 0.6 \\
Brickyard & $5.4 \mathrm{~b}$ & $82.0 \mathrm{ab}$ & 2.7 & 2.8 \\
Monticello & $5.4 \mathrm{~b}$ & $101.0 \mathrm{a}$ & 5.8 & 3.2 \\
$\quad$ Roma) & & & & \\
Richmond & $1.8 \mathrm{~b}$ & $67.0 \mathrm{~b}$ & 6.0 & 2.2 \\
Summerpick & $5.4 \mathrm{~b}$ & $74.3 \mathrm{ab}$ & 3.4 & 0.7 \\
Sanibel & $51.8 \mathrm{a}$ & $94.3 \mathrm{ab}$ & 4.5 & 2.6 \\
\hline
\end{tabular}

${ }^{\mathrm{v}}$ The field trial was set up in the field on October 22, 2015.

${ }^{\mathrm{w}}$ Disease incidence was calculated based on number of tomato plants in each plot showing typical symptoms of TCSV in the total number of plants for a given cultivar. Ratings of TCSV disease were initiated when symptoms were observed on susceptible plants of Sanibel and continued on a 3- to 4-day interval until no additional plants of Sanibel were observed with the TCSV symptoms.

${ }^{x}$ Marketable fruit were harvested on January 8, January 26, and February 17, 2016, from the center five plants in each plot.

${ }^{\mathrm{y}}$ The number of western flower thrips (Frankliniella occidentalis) and common blossom thrips (F. schultzei) adults was determined using blossom samples, in which 10 blossoms were randomly collected per plot, one blossom per plant, on December 1, 2015. No significances $(P=$ 0.05 ) in thrips density were detected among all tomato cultivars.

${ }^{\mathrm{z}}$ Means followed by the same letters within a column are not significantly different at $P=0.05$. 
further investigations are needed to determine the role of other thrips species, especially those with large populations in tomato fields of south Florida, including melon thrips (Thrips palmi) (Khan et al. 2017).

Trial 3. In this trial, disease incidence was the lowest among the three trials evaluated, which was $25 \%$ on Sanibel plants at the last rating of disease (Table 4). The 14 test cultivars had less than $3.6 \%$ disease incidence with BHN 1064, Dixie Red, 'Quincy',

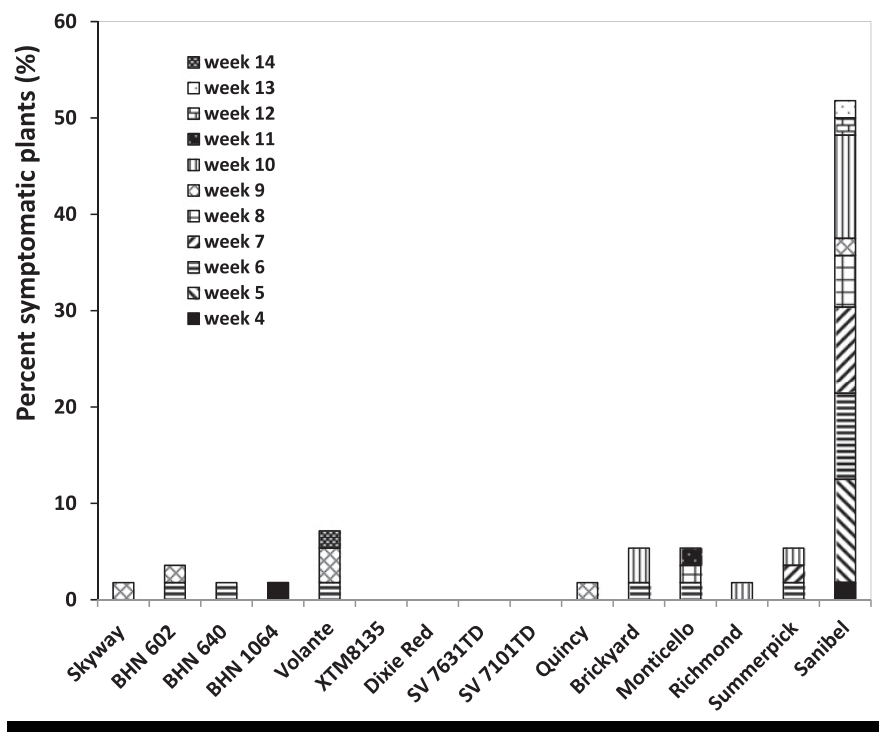

\section{FIGURE 2}

Percent of tomato chlorotic spot tospovirus infection developed weekly on tomato leaves in the field trial (trial 2) during the 2015-2016 season. A commonly cultivated cultivar, Sanibel, was included as a commercial standard check.
'Brickyard', and Monticello displaying no TCSV symptoms. Results of RT-PCR from the leaf samples with typical symptoms collected for all cultivars indicated the presence of TCSV. BHN 1064 had significantly greater yield of total, extra-large, and large fruit, compared with Sanibel. SV 7631TD and Brickyard had significantly greater extra-large fruit yield and medium fruit yield, respectively, compared with Sanibel.

\section{Implications for Management of TCSV in Tomato Production}

The disease caused by TCSV is an emerging disease in south Florida and the United States (Londoño et al. 2012). TCSV has been devastating and caused significant monetary losses to tomato growers in south Florida since 2014 (Zhang et al. 2015b). Lack of effective management options for TCSV requires immediate actions on screening germplasm for resistance against TCSV. Given the high similarity of TCSV and TSWV, integrated management strategies for TSWV would also likely be effective for control of TCSV (Polston et al. 2013). Selection of TSWV-resistant tomato cultivars could be a first choice to find out an effective solution for managing this devastating disease. Previous studies from other countries showed that tomato lines carrying the $S w-5$ gene, which confers resistance to TSWV, also provided resistance to TCSV (Kang et al. 2005; Soler et al. 2003). However, the host genetic background in germplasm and the environmental conditions may significantly affect the performance of resistance genes. More cultivars and genotypes of tomato are needed to be screened for resistance, and their performance under field conditions needs to be determined in south Florida, where TCSV has become established. In our study, 14 commercially available tomato cultivars carrying the $S w-5$ locus known to be resistant to TSWV consistently demonstrated a level of tolerance to TCSV in our field trials under varying levels of TCSV disease pressure in the 2014-2015 and 2015-2016 growing seasons. These TCSV-tolerant tomato cultivars

\begin{tabular}{|c|c|c|c|c|c|}
\hline \multicolumn{6}{|c|}{$\begin{array}{c}\text { TABLE } 4 \\
\text { Disease incidence of tomato chlorotic spot tospovirus (TCSV), fruit yield, and thrips density on tomato plants of tested } \\
\text { cultivars during the } 2015-2016 \text { season (trial 3)w }\end{array}$} \\
\hline \multirow[b]{2}{*}{ Cultivar } & \multirow[b]{2}{*}{ Disease incidence $(\%)^{x}$} & \multicolumn{4}{|c|}{ Fruit yield (kg/plot)y } \\
\hline & & Extra large & Large & Medium & Total \\
\hline Skyway & $3.6 \mathrm{~b}^{\mathrm{z}}$ & $36.5 \mathrm{a}-\mathrm{d}$ & $41.8 \mathrm{bc}$ & $14.4 \mathrm{bc}$ & $92.7 \mathrm{~b}-\mathrm{d}$ \\
\hline BHN 602 & $3.6 \mathrm{~b}$ & $38.1 \mathrm{a}-\mathrm{c}$ & $46.2 \mathrm{a}-\mathrm{c}$ & $14.8 \mathrm{bc}$ & $99.1 \mathrm{a}-\mathrm{d}$ \\
\hline BHN 640 & $1.8 \mathrm{~b}$ & $31.5 \mathrm{~b}-\mathrm{e}$ & $53.5 \mathrm{ab}$ & $18.2 \mathrm{bc}$ & $103.2 \mathrm{a}-\mathrm{c}$ \\
\hline BHN 1064 & $0.0 \mathrm{~b}$ & $41.5 \mathrm{ab}$ & $61.8 \mathrm{a}$ & $19.4 \mathrm{bc}$ & $122.7 \mathrm{a}$ \\
\hline Volante & $3.6 \mathrm{~b}$ & $44.6 \mathrm{a}$ & $47.6 \mathrm{a}-\mathrm{c}$ & $16.0 \mathrm{bc}$ & $108.1 \mathrm{ab}$ \\
\hline XТМ8135 & $1.8 \mathrm{~b}$ & 23.9 de & $38.7 \mathrm{bc}$ & $18.9 \mathrm{bc}$ & $81.4 \mathrm{~cd}$ \\
\hline Dixie Red & $0.0 \mathrm{~b}$ & $39.4 \mathrm{a}-\mathrm{c}$ & $36.5 \mathrm{c}$ & $9.4 \mathrm{c}$ & $85.2 \mathrm{~b}-\mathrm{d}$ \\
\hline SV 7631TD & $1.8 \mathrm{~b}$ & $41.3 \mathrm{ab}$ & $35.5 \mathrm{c}$ & $13.9 \mathrm{bc}$ & $90.6 \mathrm{~b}-\mathrm{d}$ \\
\hline SV 7101TD & $3.6 \mathrm{~b}$ & $31.6 \mathrm{~b}-\mathrm{e}$ & $39.5 \mathrm{bc}$ & $15.6 \mathrm{bc}$ & $86.7 \mathrm{~b}-\mathrm{d}$ \\
\hline Quincy & $0.0 \mathrm{~b}$ & $25.3 \mathrm{de}$ & $38.0 \mathrm{bc}$ & $14.7 \mathrm{bc}$ & $78.0 \mathrm{~d}$ \\
\hline Brickyard & $0.0 \mathrm{~b}$ & $27.1 \mathrm{c}-\mathrm{e}$ & $32.6 \mathrm{c}$ & $36.0 \mathrm{a}$ & $95.7 b-d$ \\
\hline Monticello (Roma) & $0.0 \mathrm{~b}$ & $\ldots$ & $\cdots$ & $\ldots$ & $91.6 \mathrm{~b}-\mathrm{d}$ \\
\hline Richmond & $1.8 \mathrm{~b}$ & $20.4 \mathrm{e}$ & $47.7 \mathrm{a}-\mathrm{c}$ & $21.4 \mathrm{~b}$ & $89.5 b-d$ \\
\hline Summerpick & $5.4 \mathrm{~b}$ & $32.1 \mathrm{a}-\mathrm{e}$ & $48.2 \mathrm{a}-\mathrm{c}$ & $18.9 \mathrm{bc}$ & $99.2 \mathrm{a}-\mathrm{d}$ \\
\hline Sanibel & $25.0 \mathrm{a}$ & $26.7 \mathrm{c}-\mathrm{e}$ & $42.4 \mathrm{bc}$ & $14.7 \mathrm{bc}$ & $83.8 \mathrm{~b}-\mathrm{d}$ \\
\hline
\end{tabular}

${ }^{\mathrm{w}}$ The field trial was set up in the field on October 23, 2015.

${ }^{\mathrm{x}}$ Disease incidence was calculated based on number of tomato plants in each plot showing typical symptoms of TCSV in a total number of plants for a given cultivar. Disease ratings were conducted on a 3- to 4-day interval until no additional plants of Sanibel were observed with the TCSV symptoms.

${ }^{y}$ Marketable fruit were harvested on January 13, February 11, and February 25, 2016, from the center five plants in each plot.

${ }^{\mathrm{z}}$ Means followed by the same letters within a column are not significantly different at $P=0.05$. 
can be incorporated into the current integrated management program for control of TCSV disease.

Field studies have been conducted at UF/IFAS North Florida Research and Education Center evaluating the effectiveness of ultraviolet (UV)-reflective mulch, plant activator acibenzolar- $S$-methyl (ASM, Actigard), and insecticides on disease progress of TSWV (Momol et al. 2004) and on population dynamics of flower thrips $F$. occidentalis, F. tritici, and F. bispinosa (Funderburk et al. 2011). Insecticide treatments with spinosad and methamidophos were effective in reducing populations of flower thrips. The combination of UV-reflective mulches, ASM, and insecticides has provided excellent management of TSWV in commercial tomato fields in northern Florida. Integrated management strategies, including the use of virusfree transplants by excluding thrips from plant houses and the use of metalized (UV-reflective) mulch in combination with insecticides for reducing development of thrips larvae, likely limit secondary virus spread. Indeed, we have observed that the incidence of TCSV was significantly reduced in a commercial tomato field using UVreflective plastic mulch compared with white plastic in Homestead in the fall of 2018 (Liu et al. 2019). In a field trial conducted in Homestead, FL, in the 2014-2015 growing season, insecticides spinetoram and cyantraniliprole significantly reduced the incidence of the TCSV disease (Zhang et al. 2015a). In another field trial in south Florida, application of imidacloprid as a soil drench followed by drip applications of Cyazypyr significantly reduced the $F$. schultzei populations and incidence of a similar tospovirus, GRSV, on tomato (Seal et al. 2014). Based on the results of the current study and previous studies, we can develop and use an integrated program to manage the TCSV disease in south Florida tomato production. This integrated program consists of the following components: plant with TCSV-tolerant tomato cultivars, use virus-free transplants, remove host weeds such as purslane and volunteer plants in and around tomato fields, apply with labeled insecticides to suppress thrips, use UV-reflective mulch for beds to repel thrips, rotate tomato with nonhost crops when possible, and isolate susceptible crops by using nonhost barrier crops to prevent virus transmission by thrips between fields.

\section{Acknowledgments}

We thank the seed companies for providing the tomato seeds used in this study. We also thank Jaimin Patel, Iray Gell, Guosheng Yao, Shagufta Bibi, and Charlie Carter for their assistance in the field trials.

\section{Literature Cited}

Baker, C. A., and Adkins, S. 2015. First report of tomato chlorotic spot virus in Hoya wayetii and Schlumbergera truncata. Plant Health Prog. 16:29-30.

Baysal-Gurel, F., Li, R., Ling, K.-S., and Miller, S. A. 2015. First report of tomato chlorotic spot virus infecting tomatoes in Ohio. Plant Dis. 99:163.

Dey, K., Melzer, M., Sun, X., and Adkins, S. T. 2017. Tomato chlorotic spot virus identified in Marsdenia floribunda in Florida. Plant Health Prog. 18: 144-145.

Estévez de Jensen, C., and Adkins, S. 2014. First report of tomato chlorotic spot virus in lettuce in Puerto Rico. Plant Dis. 98:1015.

Funderburk, J., Reitz, S., Olson, S., Stansly, P., Smith, H., McAvoy, E., Demirozer, O., Snodgrass, C., Paret, M., and Leppla, N. 2011. Managing Thrips and Tospoviruses in Tomato. EDIS publication ENY-859. University of Florida IFAS Extension, Gainesville, FL.

Kakkar, G., Seal, D. R., and Kumar, V. 2012a. Assessing abundance and distribution of an invasive thrips Frankliniella schultzei (Thysanoptera: Thripidae) in south Florida. Bull. Entomol. Res. 102:249-259.

Kakkar, G., Seal, D. R., Stansly, P. A., Liburd, O. E., and Kumar, V. 2012b. Abundance of Frankliniella schultzei (Thysanoptera: Thripidae) in flowers on major vegetable crops of south Florida. Fla. Entomol. 95:468-475.

Kang, B. C., Yeam, I., and Jahn, M. M. 2005. Genetics of plant virus resistance. Annu. Rev. Phytopathol. 43:581-621.
Khan, R., Seal, D., Zhang, S., Liburd, O., Evans, E., and Srinivasan, R. 2017. Seasonal and dial pattern of melon thrips (Thrips palmi, Karny), common blossom thrips (Frankliniella schultzei, Trybom) and western flower thrips (Frankliniella occidentalis, Pergande) in commercial tomato field. (Abstr.) Annual meeting of Entomological Society of America, Denver, CO. November 5-8, 2017.

Liu, Q., Poudel, B., Wang, Q., and Zhang, S. 2019. Impact of plastic mulch and tomato cultivar on disease incidence of tomato chlorotic spot orthotospovirus (TCSV). Presentation at the 96th annual meeting of the APS Southern Division, Gainesville, FL. February 9, 2019. https://www.apsnet.org/members/ community/divisions/south/meetings/Documents/2019\%2096th\%20Annual $\% 20$ SD-APS \%20Program_FINAL_full\%20color.pdf.

Londoño, A., Capobianco, H., Zhang, S., and Polston, J. E. 2012. First record of tomato chlorotic spot virus in the USA. Trop. Plant Pathol. 37:333-338.

Momol, T., Olson, S. M., Funderburk, J. E., Stavisky, J., and Marois, J. J. 2004. Integrated management of tomato spotted wilt in field-grown tomato. Plant Dis. $88: 882-890$.

Oetting, R. D., Beshear, R. J., Liu, X. X., Braman, K. S., and Baker, J. R. 1993. Biology and Identification of Thrips on Greenhouse Ornamentals. Georgia Agricultural Experiment Station Research Bulletin 414. University of Georgia, Griffin, GA.

Polston, J. E., Wood, E., Palmateer, A., and Zhang, S. 2013. Tomato chlorotic spot virus. UF/IFAS Cooperative Extension Service Fact Sheet PP306. http:// edis.ifas.ufl.edu/pp306. University of Florida, Gainesville, FL.

Poudel, B., Huang, Y., and Zhang, S. 2018. First report of tomato chlorotic spot virus infecting common beans (Phaseolus vulgaris) in the United States. Plant Dis. 102:1467.

Raid, R., Allingham, J., Funderburk, J., Skarlinsky, T., Hutton, S., Turechek, W., and Adkins, S. T. 2017. First report of tomato chlorotic spot virus in sweet basil (Ocimum basilicum) and purslane (Portulaca oleracea) in Florida. Plant Health Prog. 18:126-128.

Riley, D. G., Joseph, S. V., Srinivasan, R., and Diffie, S. 2011. Thrips vectors of tospoviruses. J. Integr. Pest Manage. 1:1-10.

Sargent, S. A., and Moretti, C. L. 2004. The Commercial Storage of Fruits, Vegetables, and Florist and Nursery Stocks: Tomato. USDA, ARS Agriculture Handbook 66. https://www.ars.usda.gov/is/np/CommercialStorage/ CommercialStorage.pdf. USDA, Washington, DC.

Seal, D. R., Kumar, V., and Kakkar, G. 2014. Common blossom thrips, Frankliniella schultzei (Thysanoptera: Thripidae) management and groundnut ring spot virus prevention on tomato and pepper in south Florida. Fla. Entomol. 97:374-383.

Soler, S., Cebolla-Cornejo, J., and Nuez, F. 2003. Control of diseases induced by tospoviruses in tomato: An update of the genetic approach. Phytopathol. Mediterr. 42:207-219.

Stannard, L. J. 1968. The thrips, or Thysanoptera, of Illinois. Ill. Nat. Hist. Surv. Bull. 29:215-552.

Sui, X., McGrath, M. T., Zhang, S., Wu, Z., and Ling, K.-S. 2018. First report of tomato chlorotic spot virus infecting tomato in New York. Plant Dis. 102:460.

Warfield, C. Y., Clemens, K., and Adkins, S. 2015. First report of tomato chlorotic spot virus on annual vinca (Catharanthus roseus) in the United States. Plant Dis. 99:895.

Webster, C. G., Estévez de Jensen, C., Rivera-Vargas, L. I., Rodrigues, J.-C. V., Mercado, W., Frantz, G., Mellinger, H. C., and Adkins, S. 2013. First report of tomato chlorotic spot virus (TCSV) in tomato, pepper and jimsonweed in Puerto Rico. Plant Health Prog. doi: 10.1094/PHP-2013-0812-01-BR

Webster, C. G., Frantz, G., Reitz, S. R., Funderburk, J. E., Mellinger, H. C., McAvoy, E., Turechek, W. W., Marshall, S. H., Tantiwanich, Y., McGrath, M. T., Daughtrey, M. L., and Adkins, S. 2015. Emergence of groundnut ringspot virus and tomato chlorotic spot virus in vegetables in Florida and the southeastern United States. Phytopathology 105:388-398.

Whitfield, A. E., Ullman, D. E., and German, T. L. 2005. Tospovirus-thrips interactions. Annu. Rev. Phytopathol. 43:459-489.

Wijkamp, I., Almarza, N., Goldbach, R., and Peters, D. 1995. Distinct levels of specificity in thrips transmission of tospoviruses. Phytopathology 85: 1069-1074.

Zhang, S., Fu, Y., Fan, X., Seal, D., Wang, Q., and McAvoy, E. 2016. Management of tomato chlorotic spot virus, an emerging tospovirus of tomato causing severe losses in south Florida. (Abstr.) Phytopathology 106:S4.97.

Zhang, S., Seal, D., Wang, Q., and McAvoy, E. 2015a. Evaluation of tomato cultivars and insecticides for management of tomato chlorotic spot virus (TCSV) and thrips species recorded in virus-infected tomato fields. Pages 28-30 in: Proceedings of Florida Tomato Institute.M. Ozores-Hampton and C. Snodgrass, eds. University of Florida IFAS Extension, Gainesville, FL.

Zhang, S., Seal, D. R., Wang, Q., McAvoy, E., and Polston, J. E. 2015 b. An outbreak of tomato chlorotic spot virus, an emerging tospovirus threatening tomato production in the United States. (Abstr.) Phytopathology 105: S4.156. 